\title{
官能評価によるクリ皮のむきやすさの検討
}

\author{
畑江敬子 ${ }^{1)}$, 嶋田淑子 ${ }^{1)}$, 戸田貞子 ${ }^{2)}$, 壽 和夫 ${ }^{3)}$, 香西みどり ${ }^{1)}$ \\ （1) 拉茶の水女子大学生活科学部, 2) 高崎健康福祉大学短期大学部, \\ 3) 独立行政法人 農業技術研究機構果樹研究所)
}

\section{Application of Sensory Analysis Technique to the Evaluation of Easiness of Removing Chestnut Pellicle}

\author{
Keiko HATAE ${ }^{1)}$, Yoshiko SHIMADA ${ }^{1)}$, Sadako TODA ${ }^{2)}$, \\ Kazuo KOTOBUKI ${ }^{3)}$ and Midori KASAI ${ }^{1)}$, \\ 1) Ochanomizu University, 2-1-1, Otsuka,Bunkyo, 112-8610 \\ 2) Takasaki University of Health and Welfare, 501Nakaoruimachi, \\ Takasaki,Gunma, 370-0033 \\ ${ }^{3)}$ National Institute of Fruit Tree Science, 2-1, Fujimoto, Tsukuba, \\ Ibaraki, 305-0852
}

\begin{abstract}
Japanese chestnuts are known to have pellicle difficult to peel off. To make the task easier at home and in commercial processing, some methods of pretreatment have been tried out. To evaluate each method, the sensory analysis technique has been applied. Three candidate pretreatments chosen were (1) soaking in boiling water, (2) steaming, and (3) frying. The panel composed of 11 female students removed the pellicle of pretreated chestnuts, and graded the easiness. In addition, the time needed has been measured to remove the shell and peel off the pellicle of each pretreated chestnut and untreated one. The frying method was found to be the best. It reduced the time needed by $60 \%$ compared to that for untreated samples. The steaming method was also significantly effective. Soaking in boiling water makes no effect for this purpose.
\end{abstract}

(Received 28 January 2002 ; Accepted 1 March 2002)

Keywords: Chestnuts クリ, Sensory analysis 官能評価, pellicle くり渋皮, Easiness of removing，皮むきしやすさ

\section{1. 緒言}

クリは世界的にその利用の歴史は古く，その甘 味を生かした菓子や料理が広く親しまれている。 日本では甘露煮, 羊䓺, 栗きんとん, 栗ご飯など その甘味と季節感を生かした調理が数多くあるが,
西洋料理や中国料理にもマロングラッセ，天津甘 栗などよく使われている。

しかしクリは鬼皮が硬くて包丁がすべりやすく 渋皮は剥皮性が極めて悪い. 食品加工の場でもク リの皮むきは手作業で行われており，労力を要し 
コストをあげる原因となっている.またニホングリ はヨーロッパグリにくらべると粒も大きく風味もす ぐれているといわれるが(渡辺等, 1981)，ヨーロッ パグリおよびチュウゴクグリとくらべて渋皮がはな れにくく，特に皮むきが難しいとされている．(櫻 井, 1969 ; 渡辺等, 1981 ; 主婦の友社, 1996)

クリの皮むきはクリの加工上最大の難点であるこ とから,クリ皮をむきやすくするための前処理方法 としてさまざまな方法が考案されている.塩酸・焼 きミョウバン法, カセイソーダ法, ゼラチン・石灰 法, 醭素利用法, 焙焼法など多数考えられている が,(午詰技術研究会, 1970；Manabe, 1970）Tanaka, et al. (1981) は西塩素酸ナトリウムによって胚表面 のひだを残したまま渋皮を溶解する方法を開発した.

しかし経費, 能率, 確実性, 薬品の毒性, クリ の肉質，色および味，などの点で解決すべき問題 が残されており，必ずしも実用的とは言えない. (缶詰技術研究会, 1970; 田中等, 1992)

Tanaka, et al.,（1981）は渋皮の剥皮の難易度を Peeling Score を用いることによって数量化するこ とを試みた. Peeling Scoreはナイフで渋皮を剥皮 するのに要する時間を 4 段階に区分して求めるも のであるが, パネルの構成などにおいて官能評価 の手法に基づいておらず,問題があると思われる. 水に漬ける，熱湯に漬ける，炒るなど，一般的に 家庭でも行われているほとんどの方法はもっぱら 経験によっており，それらがどの程度効果的かを
評価する方法は明確でない.

本研究ではクリ皮をむきやすくするための前処 理の効果を, 特に能率, 確実性に着目して評価寸 る方法を検討し，パネルによる評価およびクリの 皮むき時間を測定する方法で評価を試みた。

\section{2. 方法}

試料としてクリは茨城産「石錧」を用いた。官 能評価を行う前処理方法を選ぶために予備実験 （Fig.1）を行なった，予備実験は「水に漬ける」「ゆ でる」「蒸す」「沸滕水浸潰」「フライパンで炒る」 「油をまぶしてオーブン加熱 $\left(200^{\circ} \mathrm{C}, 5\right.$ 分 $)$ 」油で 揚げる $\left(160 \sim 170^{\circ} \mathrm{C}, 5\right.$ 分, 2 分) $\left(170 \sim 180^{\circ} \mathrm{C}\right.$, 3 分)」「電子レンジ加熱」の方法を検討した.

一般に調理書などでは「水に漬ける」「ゆでる」方 法が効果があるとされているが, (主婦の友社, 1981； 主婦の友社, 1996) 予備実験では鬼皮には効果が あっても，渋皮には効果がなかった．電子レンジ 処理では処理後のクリの状態が均一でなく一定し なかったむきやすさやむいたクリの肉質の状態 などから, 最終的に次の 3 種を選んだ.

（1）沸騰水浸漬:1リッ⿻川八水を沸騰させ, 火を止 めてすぐクリ 3 個を入れそのまま 5 分間浸 漬する。(クリを入れた時の水温は $93^{\circ} \mathrm{C}$ ， 最終水温は $75^{\circ} \mathrm{C}$ )

(2) 蒸す：100息の蒸し器中にクリ3個を入れて 2 分間蒸し, 火を止めて3分そのまま放置する.

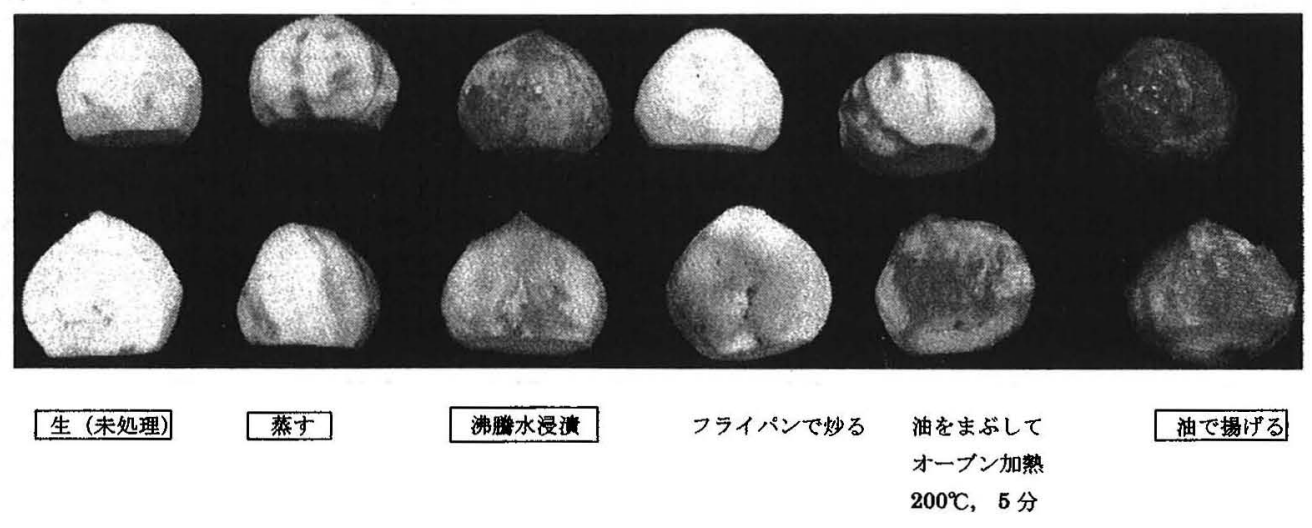

予偏実験の中から選ばれ官能テストを行った方法

Fig.1 予䚛赛験 いろいろな前処理方法で皮をむいたクリ 
日本官能評価学会誌 Vol. 6 No. 1 pp.36-40 2002 年 3 月

（3）揚げる：油温度 $160 \sim 170^{\circ} \mathrm{C}$ の中で 2 分間揚 げる、クリにはあらかじめ $2 \mathrm{~cm} \times 2 \mathrm{~cm}$ の切

り目を十文字に入れる。

官能評価の方法：パネルは女子学生11名とし,そ れぞれのパネリストが1処理方法につき3個のクリ をむき，難易度を1.むきやすい 2 .ややむきにくい

まず、最初に鬼皮だけをむいてください。 むを終わったら合図してください。

鬼皮屯周

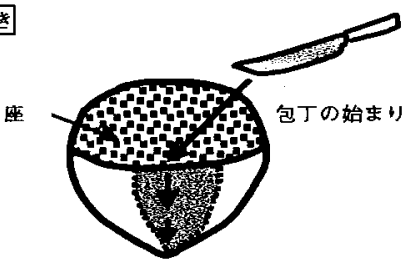

最後に座の部分をむく

次に沾皮をむいてください。

むき終わったら合図してください。

灌皮む事

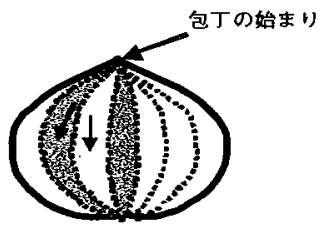

Fig.2 官能テストのための指示票
3.むきにくいの3段階で評価させた，また，それぞ れのむき時間の平均をパネルのクリむき時間とし た.パネルにはあらかじめクリのむき方について説 明した指示票 (Fig.2) を示し，包丁を入れる順序， 包丁を入れる方向などについて指示した.クリは栗 ご飯に使うクリをむくことを目標にした.包丁はぺ ティナイフを使用した. 前処理終了直後のクリをパ ネルに渡し,クリをしっかり手に持つことができる 温度になったら，クリの皮むきを開始した。最初に 鬼皮だけをむいて鬼皮のむき時間を検査員がパネル にわからないよう測定し，次に渋皮をむいて渋皮の みのむき時間を測定した。前処理前のクリの重量, 皮をむいたクリの重量を測定し収量を求めた。

なお，実験の最初と最終回に未処理のクリをむ くテストを行い，実験をくりかえすことによるむ き時間におよは寸熟練の影響を調べた。

各パネリストの未処理のクリの皮むき時間に対 する前処理したクリの皮むき時間の短縮率からむ きやすさを評価した。

\section{3. 結果}

パネルはほとんどのクリ皮むきの難易度につい て3と答えたため，結果については省略する。難

Table 23 種の方法によるクリむき時間

\begin{tabular}{|c|c|c|c|c|c|c|}
\hline \multirow[b]{3}{*}{ パネル } & \multicolumn{2}{|c|}{ 末処理 } & \multicolumn{4}{|c|}{ 沸騰水浸漬 } \\
\hline & \multirow{2}{*}{ 鬼皮 } & \multirow{2}{*}{ 啮皮 } & \multicolumn{2}{|c|}{ 鬼皮 } & \multicolumn{2}{|c|}{ 渋皮 } \\
\hline & & & 秒 & $\begin{array}{l}\text { 未処理に } \\
\text { 対する割合 }\end{array}$ & 秒 & $\begin{array}{l}\text { 未処理に } \\
\text { 対する割合 }\end{array}$ \\
\hline a & 64 & 78 & 32 & 0.50 & 54 & 0.69 \\
\hline b & 82 & 148 & 39 & 0.48 & 85 & 0.57 \\
\hline c & 111 & $\mathscr{Q}$ & 70 & 0.63 & 91 & 0.99 \\
\hline d & 122 & 113 & 60 & 0.49 & 110 & 0.97 \\
\hline$\theta$ & 82 & 117 & 44 & 0.54 & 93 & 0.80 \\
\hline$f$ & 72 & $\mathscr{Q}$ & 49 & 0.68 & 79 & 0.86 \\
\hline $\mathbf{g}$ & 95 & 105 & 61 & $0: 64$ & 90 & 0.86 \\
\hline $\mathrm{h}$ & 102 & 104 & 66 & 0.65 & 65 & 0.63 \\
\hline 1 & 52 & 51 & 38 & 0.73 & 62 & 1.22 \\
\hline j & 83 & 100 & 64 & 0.77 & 70 & 0.70 \\
\hline k & 69 & 82 & 66 & 0.96 & 120 & 1.46 \\
\hline 平均 & $86.5 a$ & $100.0 \times$ & 53.6 & $0.64 \mathrm{~b}$ & 83.6 & $0.89 \times y$ \\
\hline 標準偏差 & & & & 0.14 & & 0.27 \\
\hline
\end{tabular}

調理条件 沸騰水浸漬: 5 分間

蒸 す： $100^{\circ} \mathrm{C} 2$ 分間，余熱 3 分間

揚げる：160〜 $170^{\circ} \mathrm{C}, 2$ 分間 
官能評価によるクリ皮のむきやすさの検討

易度の段階については更に検討を要する。クリの 皮むき時間は個人差が非常に大きかった。そのた め結果については各パネリストの未処理生グリの 皮むき時間に対する短縮率を示した．実験の初回 と最終回に未炕理生グリをむき，そのむき時間を 比較しパネルが実験をくりかえすことによるむき 時間におよぼす熟練の影響を調べたが，有意の差 はなく影響は認められなかった。（Table 1)
パネリストの3種の前処理方法における皮むき 時間の短縮率をTable 2 に示した. 鬼皮について は3種すべての前処理方法で有意に皮むき時間が 短縮された。特に「揚げる」方法では30\%まで時 間を短縮できた。渋皮については標準偏差が大き かったにもかかわらず「蒸す」「揚げる」に抬い て有意 $(\mathrm{p}<0.05)$ に皮むき時間が短縮され，前 処理の効果があった。「沸滕水浸漬」では有意の

Table 1 パネルのクリむき時間の熟練による時間変化（秒）

\begin{tabular}{|c|c|c|c|c|c|c|}
\hline \multirow[b]{2}{*}{ パネル } & \multicolumn{3}{|c|}{ 鬼皮 } & \multicolumn{3}{|c|}{ 渋皮 } \\
\hline & 第 1 回 & 最終回 & 最終回／第 1 回 & 第 1 回 & 最終回 & 最終回/第 1 回 \\
\hline a & 64 & 44 & 0.69 & 78 & 74 & 0.95 \\
\hline b & 82 & 99 & 1.21 & 148 & 94 & 0.64 \\
\hline c & 111 & 131 & 1.18 & 92 & 97 & 1.05 \\
\hline d & 122 & 105 & 0.86 & 113 & 117 & 1.04 \\
\hline$\theta$ & 82 & $\approx 9$ & 1.09 & 117 & 111 & 0.95 \\
\hline$f$ & 72 & 91 & 1.26 & 92 & 86 & 0.94 \\
\hline g & 95 & 108 & 1.14 & 105 & 117 & 1.11 \\
\hline $\mathrm{h}$ & 102 & 117 & 1.15 & 104 & 102 & 0.98 \\
\hline 1 & 52 & 50 & 0.96 & 51 & 78 & 1.53 \\
\hline $\mathrm{j}$ & 83 & 91 & 1.10 & 100 & 129 & 1.29 \\
\hline $\mathrm{k}$ & $\oplus$ & 76 & 1.10 & 82 & 160 & 1.95 \\
\hline 平均 & 86.5 & 92.5 & 1.07 & 100.0 & 100.5 & 1.01 \\
\hline 標準偏差 & & & 0.17 & & & 0.35 \\
\hline T-test & & & 0.21 & & & 0.24 \\
\hline
\end{tabular}

テストの第 1 回と最終回（いずれも未処理生グリ）ではパネルのむき時間に有意の差はなかった。

の未処理生グリのむき時間に対する割合

蒸す 揚げる

\begin{tabular}{|c|c|c|c|c|c|c|c|}
\hline \multicolumn{4}{|c|}{ 蒸す } & \multicolumn{4}{|c|}{ 揚げる } \\
\hline \multicolumn{2}{|c|}{ 鬼皮 } & \multicolumn{2}{|c|}{ 漇皮 } & \multicolumn{2}{|c|}{ 鬼皮 } & \multicolumn{2}{|c|}{ 漇皮 } \\
\hline 秒 & $\begin{array}{l}\text { 末好理に } \\
\text { 対する割合 }\end{array}$ & 秒 & $\begin{array}{l}\text { 末好理に } \\
\text { 対する割合 }\end{array}$ & 秒 & $\begin{array}{l}\text { 末処理に } \\
\text { 対する割合 }\end{array}$ & 秒 & $\begin{array}{l}\text { 末処理に } \\
\text { 対する割合 }\end{array}$ \\
\hline 26 & 0.41 & 36 & 0.46 & 13 & 0.20 & 30 & 0.39 \\
\hline 75 & 0.92 & 110 & 0.74 & 37 & 0.45 & 60 & 0.41 \\
\hline 50 & 0.45 & 91 & 0.99 & 10 & 0.09 & 59 & 0.64 \\
\hline 47 & 0.39 & 113 & 1.00 & 34 & 0.28 & 94 & 0.83 \\
\hline 64 & 0.78 & 74 & 0.63 & 13 & 0.16 & 76 & 0.65 \\
\hline 56 & 0.78 & 58 & 0.63 & 36 & 0.50 & 47 & 0.51 \\
\hline $\mathscr{Q}$ & 0.97 & 42 & 0.40 & 20 & 0.21 & 58 & 0.55 \\
\hline 129 & 1.27 & 85 & 0.82 & 30 & 0.29 & 66 & 0.64 \\
\hline $\begin{array}{l}41 \\
56\end{array}$ & $\begin{array}{l}0.79 \\
0.68\end{array}$ & $\begin{array}{l}53 \\
56\end{array}$ & $\begin{array}{l}1.04 \\
0.56\end{array}$ & $\begin{array}{l}14 \\
18\end{array}$ & $\begin{array}{l}0.27 \\
0.22\end{array}$ & $\begin{array}{l}41 \\
48\end{array}$ & $\begin{array}{l}0.80 \\
0.48\end{array}$ \\
\hline 53 & 0.77 & 77 & 0.94 & 26 & 0.38 & 84 & 1.02 \\
\hline 62.6 & $0.74^{\circ}$ & 72.3 & $0.75 y$ & 22.8 & $0.28 c$ & 60.3 & $0.63 y$ \\
\hline & 0.26 & & 0.23 & & 0.12 & & 0.20 \\
\hline
\end{tabular}

パネルのむき時間は 3 回のテストの平均

a， b， c または $x, y$ :異なるアルファベット間に有意の差があることを示す（p<0.01） 
日本官能評価学会誌 Vol. 6 No. $1 \quad$ pp.36-40 2002年 3 月

差はなかった、「揚げる」方法は鬼皮 で約30\%，渋皮で約60\%まで時間を 短縮でき，3種の方法の中ではをき 時間の短縮効果が最も大きかった。

「沸騰水浸漬 5 分」の条件では渋皮に ついて未処理と有意の差はなく，前 処理の効果としてはそれほど有効ではなかった。 調理書（主婦の友社, 1981 ; 主婦の友社, 1996) に記されている「沸騰水浸漬」「水に漬ける」「ゆで る」方法では，鬼皮には効果があっても，内部の 渋皮まではむきやすさの効果はおよばなかったと いえる。

またクリの重量測定の結果, 3 方法すべて未処 理のクリ $(60.5 \%)$ より収量があがったが「揚げ る」方法で廃率率が小さく，収量が $65.1 \%$ と最も 多かった. (Table 3)

\section{4. 考察}

予備実験としていろいろな前処理の方法を検討 したが，前処理後の状態が一定でクリの個体差が なるべく小さく均一に処理できる方法を選んだ。 その点では「沸騰水浸漬」,「蒸す」の方法が適し ていた。またむいたクリの肉質がくずれたり，過 加熱になったりすることのないよう温度や時間の 条件を検討した。しかしそれぞれ目的とするクリ の調理方法によってそれぞれ適した前処理方法が あり，肉質に与える影響も許される点が違うため， さらに検討が必要である。

皮のむき時間と収量の両方で最も大きな効果が みとめられた「揚げる」方法では揚げ加熱中の破 裂を防ぐために十文字に $2 \mathrm{~cm} \times 2 \mathrm{~cm}$ の切り目を入 れたが，この切り目が大きな効果を作りだした可 能性がある，表面がわずかに油の影響を受けても よい場合，特に中華料理などは収量の点からも前 処理の方法として「揚げる」方法が効果的である といえる。

また，栗ご飯に使うクリを目的として皮むきを したが、これでむき終わったと判断されたできあ がりの状態は個人差が大きかった，官能評価の方 法として皮のむき時間を測定したが，想像以上に
Table 3 処理方法によるクリの収量の比較

未処理に対する割合

1.00

$1.04 \pm 0.07$

$1.02 \pm 0.07$

$1.07 \pm 0.09$

時間もパネルの個人差が大きかった。しかし個人 内では一定していることがわかった．皮むき時間 の初回と最終回を比較したが，この実験回数では 熟練の影響は無いことを確認した。

\section{5. 要約}

ニホングリの皮むきを容易にするための3種の 前処理の効果を評価した.「沸騰水浸漬」「蒸す」 「揚げる」の3種の方法で評価を行った. 11 名か ら成るパネルが 1 処理方法につきクリ 3 個をむ き，鬼皮と渋皮をむく時間を測定した．皮むき時 間は「蒸す」および「揚げる」方法によって短縮 し，特に「揚げる」方法は未処理に対し60\%まで 時間の短縮が可能となった. 沸騰水浸漬の効果は 渋皮のむき時間ではみられなかった。

\section{引用文献}

缶詰技術研究会糄 (1970) 缶詰技術事典, 缶詰技術研 究会, 東京, 74

Manabe, N., (1970) Studies on the constituents and processing methods of Japanese chestnuts. Part VII, A trial for removing both inner peel and the most outside layer in the edible portion of chestnut with chemical reagents.

J. Jpn. Soc. Food Sci .Technol. 17, 247-251

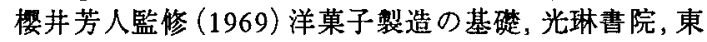
京, 121

主婦の友社編（1981）料理実用大事典，主婿の友,東 京, 170

主婦の友社編（1996）料理食材大事典,主婦の友社, 東 京, 249

Tanaka, K., Kotobuki, K., and Kakiuchi, N. (1981) Numerization of peeling easiness and role of phenolic compounds of the pellicle in the adhesion between the pellicle and embryo in comparison of Japanese (Castanea crenata Sieb.et Zucc) and Chinese(Castanea mollissima Blume) chestnuts, J. Japan. Soc. Hort. Sci. 50 (3), 363-371

田中敬一, 壽 和夫 (1992) 二ホングリの啮皮剥皮性 に関与寸る要因の組織的・化学的解析, 園学誌, 61(1), $1-6$

渡辺長男, 鈴木繁男, 岩尾裕之, 小原哲二郎 編 (1981) 製菓事典, 朝倉書店, 東京, 168 